\title{
Uncharacterized Protein C10orf107
}

National Cancer Institute

\section{Source}

National Cancer Institute. Uncharacterized Protein C10orf107. NCI Thesaurus. Code C116101.

Uncharacterized protein C10orf107 (208 aa, $24 \mathrm{kDa}$ ) is encoded by the human CABCOCO1 gene. This protein may play a role in blood pressure regulation. 